\title{
Influenza: Historia y amenazas
}

\author{
GUILLERMO ACUÑA L.
}

\author{
Influenza: History and threats
}

Durante la primera guerra mundial, en la primavera de 1918, los rusos llegaron a un armisticio con Alemania, lo que permitió a esta última cerrar ese frente y concentrar más de un millón de hombres en la lucha en Francia. Estados Unidos recién entraba en esta guerra y su presencia aún no planteaba una ayuda real a los aliados. El avance alemán se hizo sentir, en muchos lugares las tropas germanas aventajaban en una proporción de 4 a 1 a las tropas aliadas. Se conquistaron 1.250 millas cuadradas en cuatro meses lo que era un gran avance en esta guerra de trincheras. En mayo habían llegado al río Marne poniendo a su artillería pesada a tiro de París. La población civil inició la evacuación de París.

No fue el heroísmo de los aliados o la influencia de los americanos, sino que una epidemia, la que diezmó a las tropas germanas deteniendo el avance y permitiendo que el aparato bélico americano alcanzara la magnitud suficiente para cambiar el curso de la historia. Dicha epidemia, que afectó también a las tropas aliadas y al mundo en general, fue la influenza o gripe española, como es conocida. Su nombre no se debe a que haya surgido la epidemia en España sino que simplemente porque, al ser España neutra en esta guerra, no existía impedimento en reportar públicamente una epidemia que en los otros países se consideraba información privilegiada.

La primera guerra mundial produjo una gran cantidad de muertes; sin embargo, se estima que la epidemia de influenza fue responsable de 20 a 40 millones de muertos en menos de un año, dos a cuatro veces más que el total de las muertes en cuatro años de guerra. Se calcula que un quinto de la población mundial fue infectada y que 2 a $3 \%$ de los infectados murieron.

A diferencia de otras epidemias, la pandemia de influenza de 1918-19, fue letal no sólo en ancianos y personas debilitadas, sino que también en adultos sanos. La mayoría de las pérdidas humanas de las tropas americanas en Europa no fue debida al fuego enemigo, la mayoría (casi $80 \%)$ de estos jóvenes murió por efecto de la influenza (43.000 soldados).

La Asociación Médica Americana (AMA) reportó que un tercio de la muerte de médicos fue fruto de la infección.

Nuestro país reportó 23.789 muertes, en una población que sumaba 3,6 millones para 1919.

Aunque el conocimiento etiológico de las epidemias es relativamente reciente, ya Hipócrates (412 aC) describía lo que parece haber sido epidemias de influenza. Las descripciones continuaron en Roma y luego la durante la Edad Media.

La primera descripción clara de influenza se atribuye al médico americano Robert Johnson, un facultativo de Filadelfia quien describió una epidemia de 1793. Siguiendo esta descripción hay antecedentes de epidemias en los anales de la salud pública en los años 1833, 1837, 1847, 1889-90 y en 1918.

Respecto a la etiología, el investigador alemán Richard Pfeiffer estudió la expectoración de pacientes con un cuadro clínico de influenza, detectando gran cantidad de bacterias; al filtrar los líquidos en bujías del tipo Pasteur-Chamberland, no obtenía material infectante, hecho que indujo a este investigador y a otros a plantear una etiología bacteriana de la influenza

\section{Etiología}

Es común dar por hecho que la etiología de las infecciones se ha conocido de siempre, pero tras cada una de ellas ha habido uno o varios cazadores de microbios que con mucho esfuerzo e ingenio han logrado demostrar los agentes etiológicos de las diferentes enfermedades.

Hospital Clínico, Pontificia Universidad Católica de Chile.

Clínica las Condes.

Hospital del Trabajador.

Recibido: 3 marzo 2004

Aceptado: 10 marzo 2004 


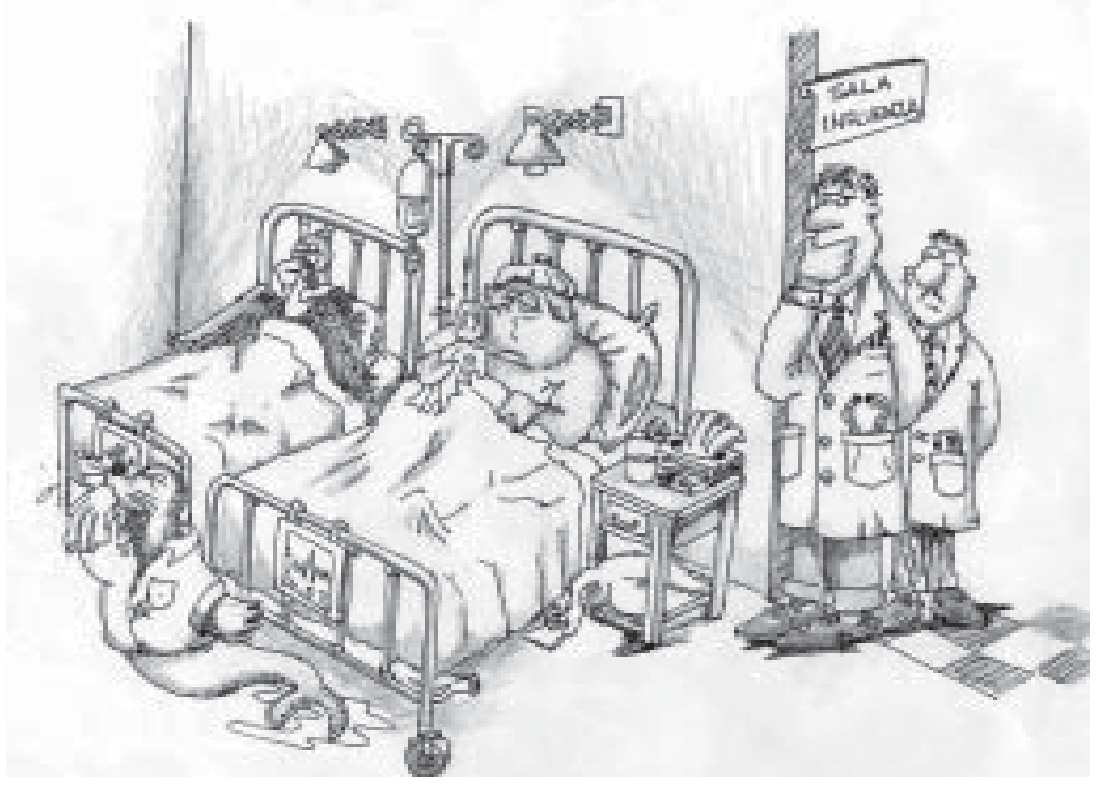

En el caso de influenza, esta historia trata de cerdos, perros cazadores, zorros y hurones.

En 1918, el inspector de la oficina de industria animal de E.U.A. describió una enfermedad en cerdos, muy similar en sintomatología a la grave epidemia de influenza de los años 1918-19. Su observación no tuvo mucha repercusión, en especial por la gran oposición de los productores de carne de cerdo, quienes se sintieron amenazados. Diez años después, en 1928, se describió el paso de la infección de un cerdo a otro; sin embargo, no se logró evidenciar una etiología viral. El Dr. Richard Shope del Departamento de Patología Comparativa del Instituto Rockefeller en Princeton, fue el primero en reproducir la influenza en cerdos sanos, inoculando material obtenido de cerdos enfermos que había sido filtrado mediante la cámara de Pasteur-Chamberland. Esta fue la primera evidencia de una etiología viral de la influenza porcina.

A fines del siglo XIX y principios del XX los aristócratas ingleses que practicaban la cacería del zorros, estaban muy preocupados por la muerte de sus sabuesos por distemper. El virus del distemper, que pertenece a la misma familia que el virus del sarampión, produce una infección respiratoria frecuentemente complicada con manifestaciones neurológicas que paralizan, y luego matan a los perros. Este grupo juntó dinero para iniciar la investigación sobre esta enfermedad en la búsqueda de una vacuna protectora. Esto se hizo en conjunto con la empresa BurroughsWellcome (hoy GlaxoSmithKline), lográndose desarrollar la primera vacuna para el distemper el año 1928.
La investigación tuvo problemas, en especial con el uso de perros como animales de laboratorio, algunos eran inmunes por exposición previa al virus del distemper pero, sobre todo, la sociedad protectora de animales y la sociedad en general se oponían al empleo del "mejor amigo del hombre" como animal de experimentación. Esto se superó cuando los perros fueron reemplazados por hurones, por fortuna también susceptibles al distemper.

En 1933, una nueva epidemia de influenza afectó a un porcentaje de la población, incluyendo a personal de Burroughs-Wellcome. Inesperadamente los hurones también enfermaron, con síntomas como estornudos, tos, y sibilancias. El Dr. Wilson Smith entonces tomó muestras de faringe de personas con influenza, las pasó por el filtro de la cámara de Pasteur-Chamberland e inoculó en hurones sanos. Pronto se comprobó la infección en estos animales, lo que demostró por primera vez que la etiología de la influenza humana era viral, a la vez que se cumplían los postulados de Koch.

El científico australiano Maxfarlane Burnet, introdujo el uso de huevos fecundados como medio de cultivo, y George Hirst introdujo la hemoaglutinación como método diagnóstico para la infección por influenza.

Los virus influenza que afectan al hombre se dividen en tres serotipos: A, B y C. El influenza A es el responsable de epidemias que afectan no sólo al hombre sino que, a cerdos, caballos, focas y una gran variedad de aves. Se ha aislado virus influenza de aves domésticas y silvestres, fundamentalmente aves acuáticas como pato, 
gansos, golondrinas marinas, gaviotas y aves domésticas como pavos, pollos, codornices, faisanes, gansos y patos.

Estudios de biología molecular apuntan a que los virus humanos pueden tener su origen en aves acuáticas. Los virus aviarios crecen difícilmente en el hombre y viceversa, pero ambos (de origen aviar o humano) se desarrollan bien en el cerdo.

En Asia es muy frecuente la convivencia de cerdos, patos y hombre. El traspaso de virus entre las especies facilita los cambios antigénicos propios de este virus. Se piensa que en la naturaleza la infección de cerdos con cepas provenientes de aves y humanos convierte al cerdo en un escenario propicio para la producción de cambios y generación de virus con diferentes características antigénicas.

Esto ha hecho necesario estar monitoreando los cambios antigénicos de los virus aislados, especialmente los cambios de la hemaglutinina (H) una glicoproteína importante en el virus, ya que su división en dos partes es importante para la infectividad del virus. Cambios en la hemaglutinina y en la neuroaminidasa $(\mathrm{N})$ se observaron en las distintas epidemias:

1933: H1N1

1957: H2N2 (gripe asiática)

1968: H3N2 (gripe de HongKong)

1977: reaparición de H1N1 (gripe rusa)

Todos estos cambios hacen que el virus no sea adecuadamente detectado y neutralizado por los mecanismos inmunitarios, y que la vacuna que protege contra determinado tipo de virus no sea eficaz para uno diferente. Por ello es necesario inmunizar anualmente a la población en mayor riesgo de complicaciones y al personal de salud. La vacuna de la influenza no tiene la efectividad de otras vacunas virales.

Todos estos cambios hacen que el virus no sea adecuadamente detectado y neutralizado por los mecanismos inmunitarios, y que la vacuna que protege contra determinado tipo de virus no sea eficaz para uno diferente. Por ello es necesario inmunizar anualmente a la población en mayor riesgo de complicaciones y al personal de salud. La vacuna de la influenza no tiene la efectividad de otras vacunas virales.

\section{Desafíos}

La producción mundial de vacunas tiene una serie de desafíos en el presente y para el futuro. Los estándares de calidad han exigido cada vez mayores inversiones mientras el potencial de efectos adversos, en especial los derivados de presuntas malformaciones fetales, hacen que la producción de vacunas sea altamente riesgosa para la mayoría de las empresas de punta; muchas de las industrias farmacéuticas elaboradoras de vacunas han firmado contratos con los Estados, estableciendo responsabilidades compartidas para el caso de presentación de efectos adversos severos.

La producción de la vacuna anti-influenza obliga cada año a un esfuerzo coordinado de los países para mantener un alerta epidemiológico, estudiar las variaciones antigénicas de los virus circulantes y luego en poco tiempo desarrollar una vacuna apropiada.

El interés de países como E.U.A en desarrollar vacunas contra posibles armas de bioterrorismo ha hecho que disminuyan su interés prioritario en una enfermedad que puede tener serias repercusiones en la salud y la economía de un país. Esto ha llevado al Presidente de la Sociedad Americana de Infectología (IDSA) Dr. W. Michael Scheld, a dirigirse al Secretario de Salud de ese país haciéndole ver lo vulnerable que es E.U.A. frente a una posible pandemia siendo que la mayor producción de vacunas está centrada en Europa y no en E.U.A. En dicha carta el apunta a tres puntos estratégicos:

- Impulsar el uso de genética reversa para la producción de los partidores en contra de la cepas candidatas para pandemias y también aquellas seleccionadas por la Organización Mundial de la Salud en los períodos inter pandémicos.

- Hacer un listado de todas las empresas que intenten producir vacunas para la pandemia.

- Desarrollar e implementar un protocolo internacional común de inmunogenicidad y seguridad de las vacunas producidas por estas compañías.

Existe una genuina preocupación por la posibilidad de una pandemia, la cual pudiera originarse en estos brotes de influenza aviar que actualmente se desarrollan en el Asia.

\section{Bibliografía}

1.- Liddel Hart. A Complete History of the World War. New York, 1936.

2.- Beveridge W. Influenza: The last great plague. New York, 1978.

3.- Crosby L A. Epidemic and peace. 1918, Westport Ct.

4.- Stuart Harris C H, Schild G C. Influenza: The Virus and the Disease. Littleton. Mass.1976

5.- Thompson T. Annals of influenza or epidemic catarrhal fever in Great Britain from 1510-1837, London, 1852.

6.- Skehel J. The discovery of human influenza virus and subsequent influenza research at the National Institute of Medical Research. In Microbe Hunters: Then and Now, ed. H.Koprowski and M.B.A Oldstone, pp.20510. Bloomington, Ill, 1996.

7.- Smith W, Andrews C H, Laidlow P P. A virus obtained from influenza patients. Lancet (1933): 66.

Correspondencia a: Guillermo Acuña Leiva

E-mail:gacuña@netline.cl 